\title{
Role of the Guanine N1 Imino Proton in the Migration and Reaction of Radical Cations in DNA Oligomers
}

\section{Supporting Information}

\author{
Avik K Ghosh and Gary B. Schuster* \\ School of Chemistry and Biochemistry, Georgia Institute of Technology, \\ Atlanta, Georgia 30332
}

\section{Materials and Methods}

TdT enzyme and $\left[\alpha-{ }^{32} \mathrm{P}\right] \mathrm{ATP}$ were purchased from Amersham Biosciences. Formamidopyramidine glycosylase (Fpg enzyme) was purchased from Trevigen, Gaithersburg, MD. DNA oligomers were synthesized as described elsewhere ${ }^{1}$ on an Expedite 8909 DNA synthesizer. Nucleotide phosphoramidites and $O$-TMP protected 5fluoro-2'-deoxyuridine phosphoramidite were obtained from Glen Research and used as received. $O$-TMP protected 5-fluoro-2'-deoxyuridine was converted to 5-fluoro-2'deoxycytidine $\left(\mathrm{F}^{5} \mathrm{dC}\right)$ by heating the oligonucleotide overnight with ammonia at $60^{\circ} \mathrm{C}$. The extinction coefficients of the oligomers were calculated using a biopolymer calculator, and their concentrations were determined from the absorbance at $260 \mathrm{~nm}$. An adenine is substituted for the anthraquinone group in the extinction coefficient calculation. The oligonucleotides were purified by means of reversed phase HPLC on a Hitachi preparative HPLC system using a Dynamax C18 column. Purified oligomers were desalted and characterized by mass spectroscopy. UV melting and cooling curves were recorded on a Cary $1 \mathrm{E}$ spectrophotometer equipped with a multicell block, temperature controller, and sample transport accessory. CD spectra were recorded on a JASCO spectrapolarimeter.

Preparation of Radiolabeled DNA. The oligomers were radiolabeled at the 3'-end using $\left[\alpha-{ }^{32} \mathrm{P}\right] \mathrm{ATP}$ and TdT enzyme. A $5 \mu \mathrm{L}$ sample of desired single stranded DNA was incubated with $1 \mu \mathrm{L}$ of $\left[\alpha^{3}{ }^{32} \mathrm{P}\right] \mathrm{ATP}$ and $2 \mu \mathrm{L}$ of TdT enzyme in a total volume of $20 \mu \mathrm{L}$ at 37 ${ }^{0} \mathrm{C}$ for $45 \mathrm{~min}$. After incubation, the DNA sample was suspended in a denaturing loading dye and was purified on a $20 \%$ denaturing polyacrylamide gel. The desired DNA band was excised from the gel and eluted with $800 \mu \mathrm{L}$ of elution buffer $\left(0.5 \mathrm{M} \mathrm{NH}_{4} \mathrm{OAc}, 10 \mathrm{mM}\right.$ 
$\mathrm{Mg}(\mathrm{OAc})_{2} / 1.0 \mathrm{mM}$ EDTA/0.1\% SDS $)$ at $37{ }^{0} \mathrm{C}$ for $12 \mathrm{~h}$. The DNA was precipitated from the supernatant by addition of $600 \mu \mathrm{L}$ of cold ethanol and $2 \mu \mathrm{L}$ of glycogen. The mixture was vortexed, placed on dry ice for about $60 \mathrm{~min}$, and centrifuged at $13000 \mathrm{rpm}$ for $45 \mathrm{~min}$. The supernatant was removed, and the residual DNA was washed with $100 \mu \mathrm{L}$ of $80 \%$ ethanol and air-dried. Suitable volumes of water were added for further experimentation.

UV Irradiation and Cleavage Analysis. Samples for irradiation were prepared by hybridizing a mixture of unlabeled $(5.0 \mu \mathrm{M})$ and radiolabeled $(10000 \mathrm{cpm})$ oligonucleotides with complimentary AQ-linked DNA in sodium phosphate buffer solution at $\mathrm{pH}$ 7.0. Hybridization was achieved by heating the samples at $90{ }^{\circ} \mathrm{C}$ for $10 \mathrm{~min}$, followed by slow cooling at room temperature for $3 \mathrm{~h}$. Samples were irradiated at ca. $30{ }^{0} \mathrm{C}$ in microcentrifuge tubes in a Rayonet Photoreactor (Southern New England Ultraviolet Co., Bransford, CT) equipped with two $350 \mathrm{~nm}$ lamps. After irradiation, the samples were precipitated once with cold ethanol $(100 \mu \mathrm{L})$ and $2 \mu \mathrm{L}$ of glycogen. The precipitated samples were washed twice with $100 \mu \mathrm{L}$ of $80 \%$ ethanol and dried. Then the samples were mixed with $3 \mu \mathrm{L}$ of Fpg enzyme, $2 \mu \mathrm{L}$ of buffer solution and diluted to $20 \mu \mathrm{L}$ with nanopure water, heated at $37{ }^{0} \mathrm{C}$ for $2 \mathrm{~h}$ and then at $90^{\circ} \mathrm{C}$ for $20 \mathrm{~min}$. The samples were then reprecipitated with cold ethanol $(100 \mu \mathrm{L})$ and $2 \mu \mathrm{L}$ glycogen and the precipitated samples were washed with $100 \mu \mathrm{L}$ of $80 \%$ ethanol. After evaporation of ethanol, the samples were dissolved in denaturing loading dye and subjected to $20 \%$ 19:1 polyacrylamide gel electrophoresis. The gels were dried, and the cleavage sites were visualized by autoradiography. Quantification of cleavage bands was performed on a Fuji phosphorimager. Figure S2 shows analysis of the relative amount of strand cleavage for DNA(1) at irradiation times of 4 and $8 \mathrm{~min}$, which are the same within experimental error confirming "single-hit" conditions.

Synthesis of 5-fluorocytidine. 5-Fluorocytidine used for $\mathrm{pKa}$ studies was synthesized according to conditions described by Vorbrugen ${ }^{2}$ as shown in Scheme S1.

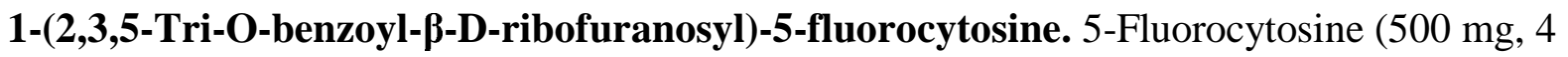
mmol) was suspended in toluene $(20 \mathrm{~mL})$ and hexamethyldisilazane $(1 \mathrm{~mL}, 4 \mathrm{mmol})$ and the mixture was heated at reflux for $3 \mathrm{~h}$, cooled to room temperature and evaporated to dryness. The residue was dissolved in dry dichloroethane $(20 \mathrm{~mL})$ and was added to a mixture of 1acetyl-2,3,5-tri-O-benzoyl- $\beta$-D-ribofuranose (1.24 g, $2.5 \mathrm{mmol})$ and TMS-triflate $(0.72 \mathrm{~mL}$, $3.96 \mathrm{mmol}$ ). The reaction mixture was stirred for $8 \mathrm{~h}$ at room temperature diluted with 
chloroform $(100 \mathrm{~mL})$, washed with $5 \% \mathrm{NaHCO}_{3}$ solution, dried over $\mathrm{Na}_{2} \mathrm{SO}_{4}$, filtered, and the solvent was evaporated leaving a white crystalline compound that was purified by column chromatography (0-10\% methanol in dichloromethane) to obtain pure 1-(2,3,5-tri-Obenzoyl- $\beta$-D-ribofuranosyl)-5-fluorocytosine (1.3 g, 91\% yield).

${ }^{1} \mathbf{H}$ NMR $\left(\mathrm{CDCl}_{3}\right): \delta 8.2(\mathrm{~d}, 1 \mathrm{H}, \mathrm{H}-6), 8.1-7.3\left(\mathrm{~m}, 15 \mathrm{H}, 3 \mathrm{C}_{6} \mathrm{H}_{5} \mathrm{CO}\right), 6.17$ (dd, $1 \mathrm{H}, \mathrm{H}-1$ '), 5.9-5.7 (m, 2H, H-2', H-3'), 4.85-4.75 (m, 3H, H-4', H-5', H-5' ').

ESI $(\mathrm{m} / \mathrm{z}): 1147(2 \mathrm{M}+\mathrm{H})^{+}, 574(\mathrm{M}+\mathrm{H})^{+}$.

5-Fluorocytidine. $1.3 \mathrm{~g}$ (2.26 mmol) of 1-(2,3,5-tri-O-benzoyl- $\beta$-D-ribofuranosyl)-5-

fluorocytosine was dissolved in $40 \mathrm{~mL}$ of methanolic ammonia $(7 \mathrm{~N})$ and was stirred at room temperature overnight; the solvent was evaporated to dryness, and then again coevaporated with methanol. The residue was dissolved in $100 \mathrm{~mL}$ of water, which was washed six times with $\mathrm{CH}_{2} \mathrm{Cl}_{2}(100 \mathrm{~mL})$ and evaporated to obtain $550 \mathrm{mg}(92 \%)$ of crystalline 5-fluorocytidine as a white powder.

${ }^{1}$ H NMR (DMSO-d 6 ): $\delta 8.2$ (d, 1H, H-6), 7.7-7.5 (broad d, 2H, -NH2), 5.7 (dd, 1H, H-1'), 5.4 (s, 1H, 2'-OH), 5.2 (s, 1H, 5'-OH), 5.0 (s, 1H, 3'-OH), 4.1-3.6 (m, 5H, H-2', H-3', H-4', H-5, H-5', ) .

ESI $(\mathrm{m} / \mathrm{z}): 523(2 \mathrm{M}+\mathrm{H})^{+}, 262(\mathrm{M}+\mathrm{H})^{+}$.

pKa measurement of nucleotides. The $\mathrm{pKa}$ of $\mathrm{dC}$ and $\mathrm{F}^{5} \mathrm{C}$ were determined by measuring the changes in their UV absorption spectra in water solution as a function of $\mathrm{pH}$. Solutions $\left(10^{-4} \mathrm{M}\right)$ of cytidine and 5-fluorocytidine were prepared and aliquots of a dilute, standard $\mathrm{H}_{2} \mathrm{SO}_{4}$ solution were added. After each addition the $\mathrm{pH}$ of the solution was measured by Orion pHmeter (Model 250A) and the absorption spectra were recorded using HP spectrophotometer. The first derivative of absorbance was plotted against $\mathrm{pH}$ to obtain the pKa of the nucleobase (Figures S3): pKa dC $=4.4(\text { lit. } 4.3)^{3}, \mathrm{pKa} \mathrm{dF}^{5} \mathrm{C}=2.7$.

\section{References}

1) Gasper, S. M.; Schuster, G. B. J. Am. Chem. Soc. 1997, 119, 12762-12771.

2) Vorbruggen H., Krolikiewicz K., Bennua B., Chem. Ber. 1981. 14 1234-1255

3) Burrows, C, J.; Muller, J G. Chem. Rev. 1998, 98, 1109-1151 


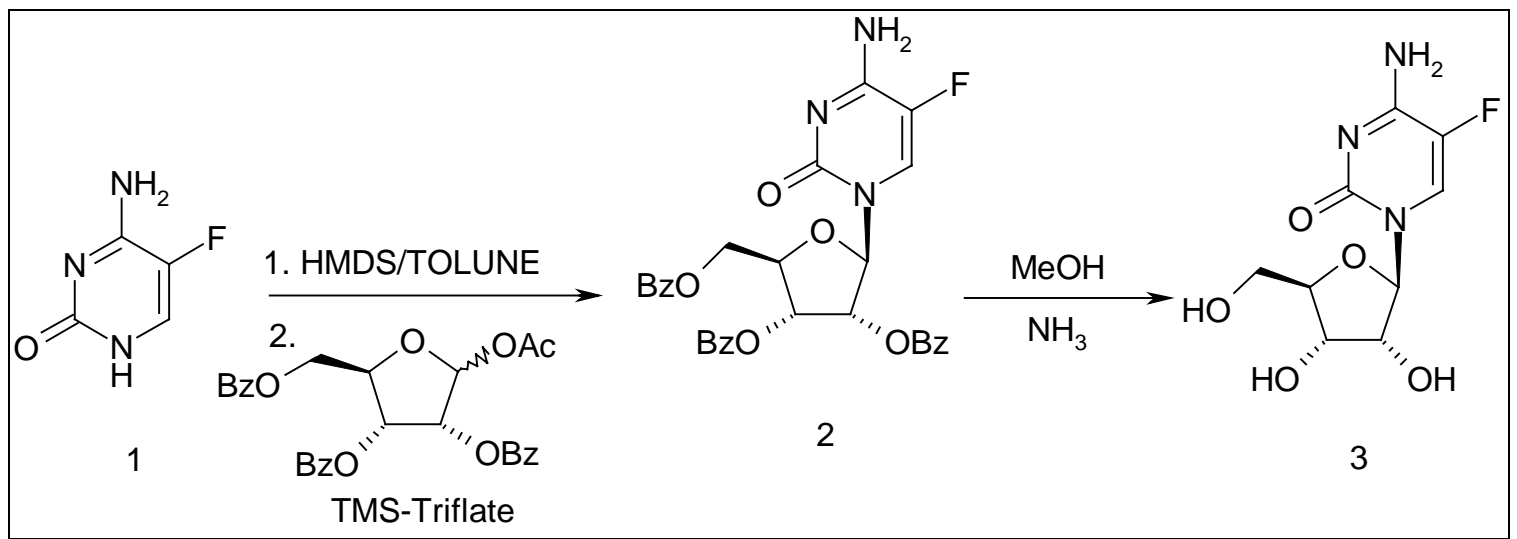

Scheme S1: Synthesis of 5-fluorocytidine 


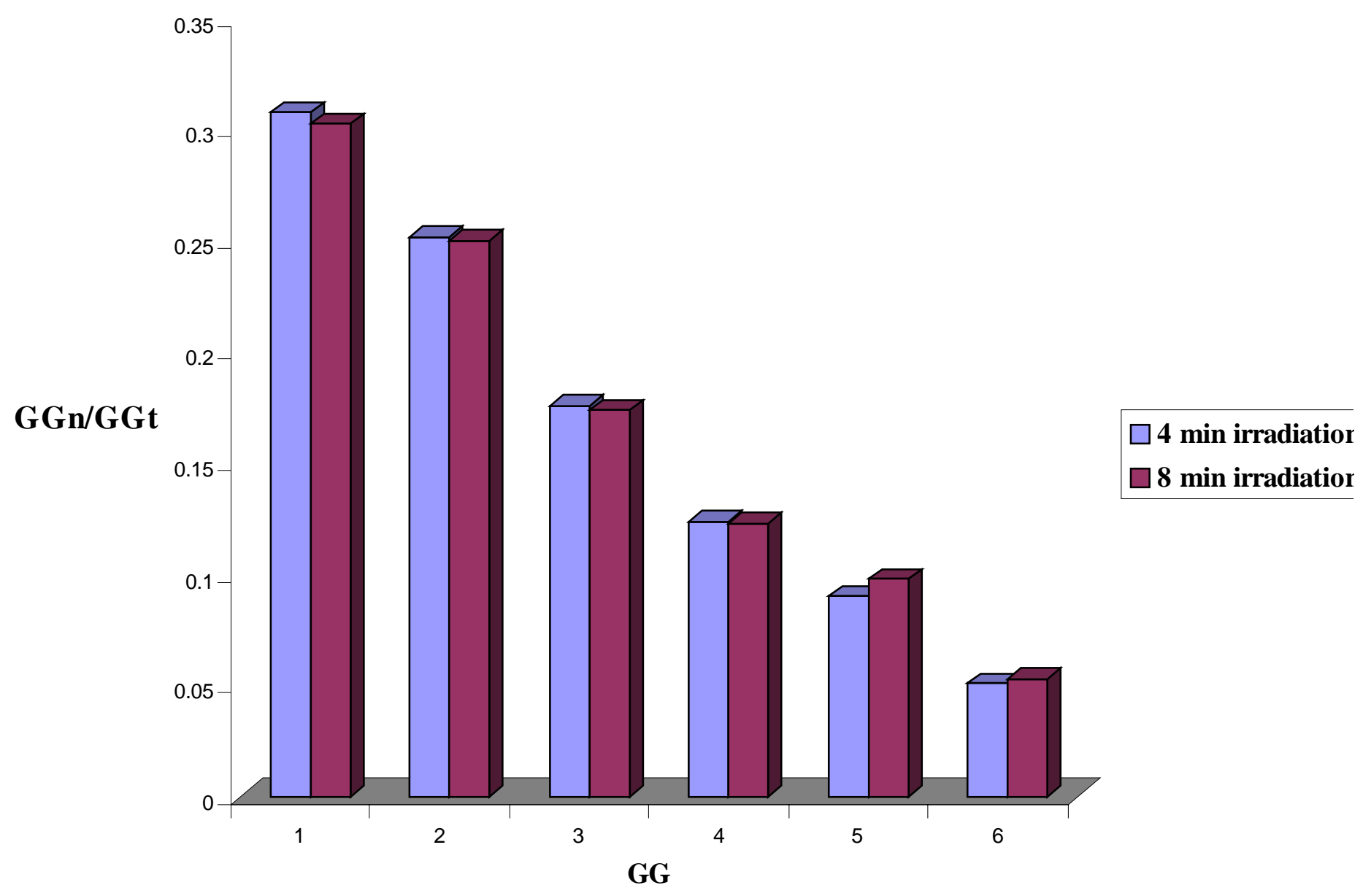

Figure S2. Histogram indicating the amount of damage at each GG step relative to the total damage at all GG steps for 4 min of irradiation and 8 min of irradiation of DNA(1). The ratio of damage does not depend on the extent of reaction (time of irradiation), which indicates that the experiments at 4 and 8 min of irradiation are within single hit conditions. 

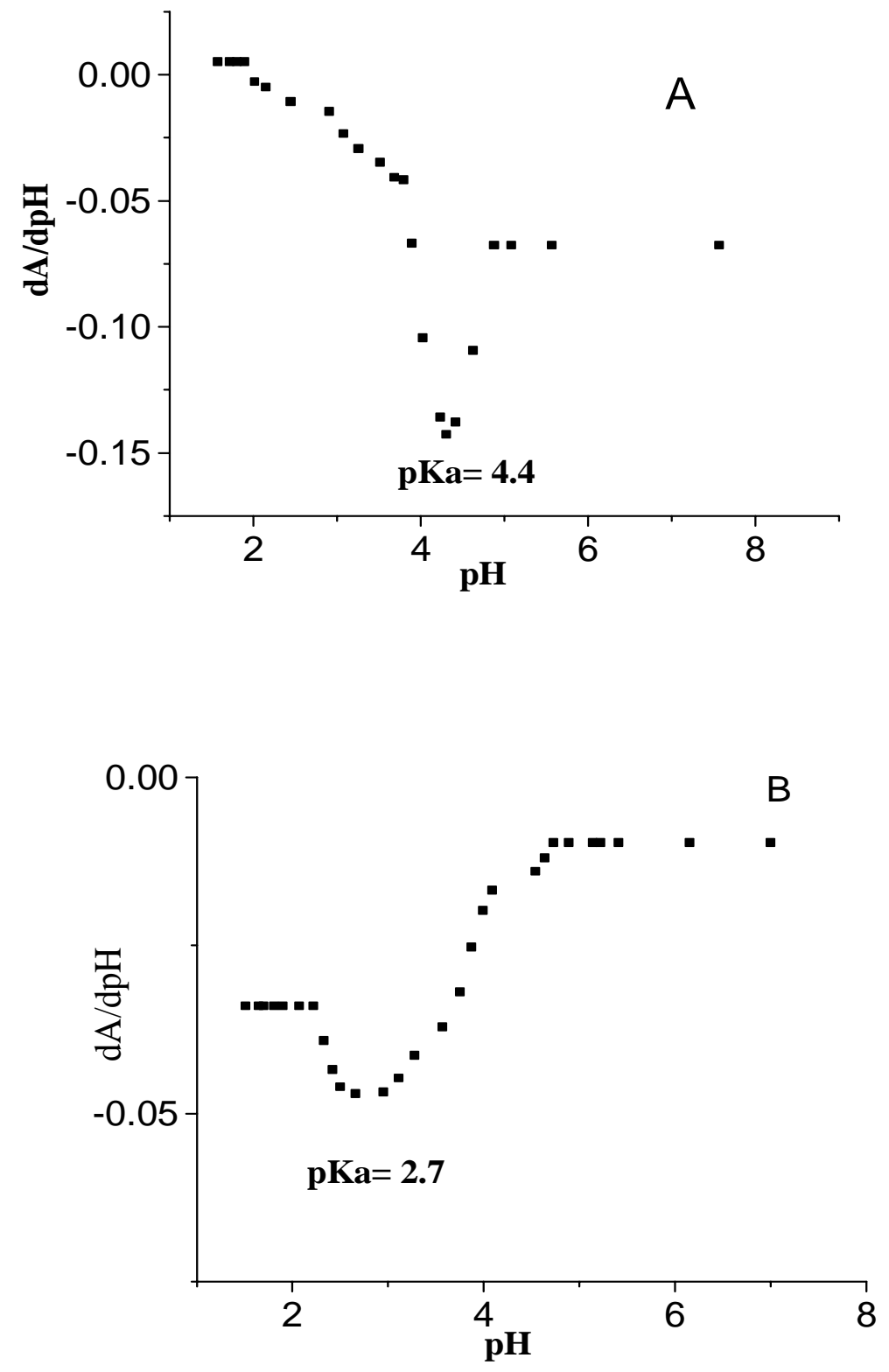

Figure S3. (A) First derivative plot of the change in absorption for $\mathrm{dC}$ as a function of $\mathrm{pH}$. (B) First derivative plot of the change in absorption for $\mathrm{F}^{5} \mathrm{C}$ as a function of $\mathrm{pH}$. The $\mathrm{pKa}$ of the nucleobases is assigned to the inflection point. 


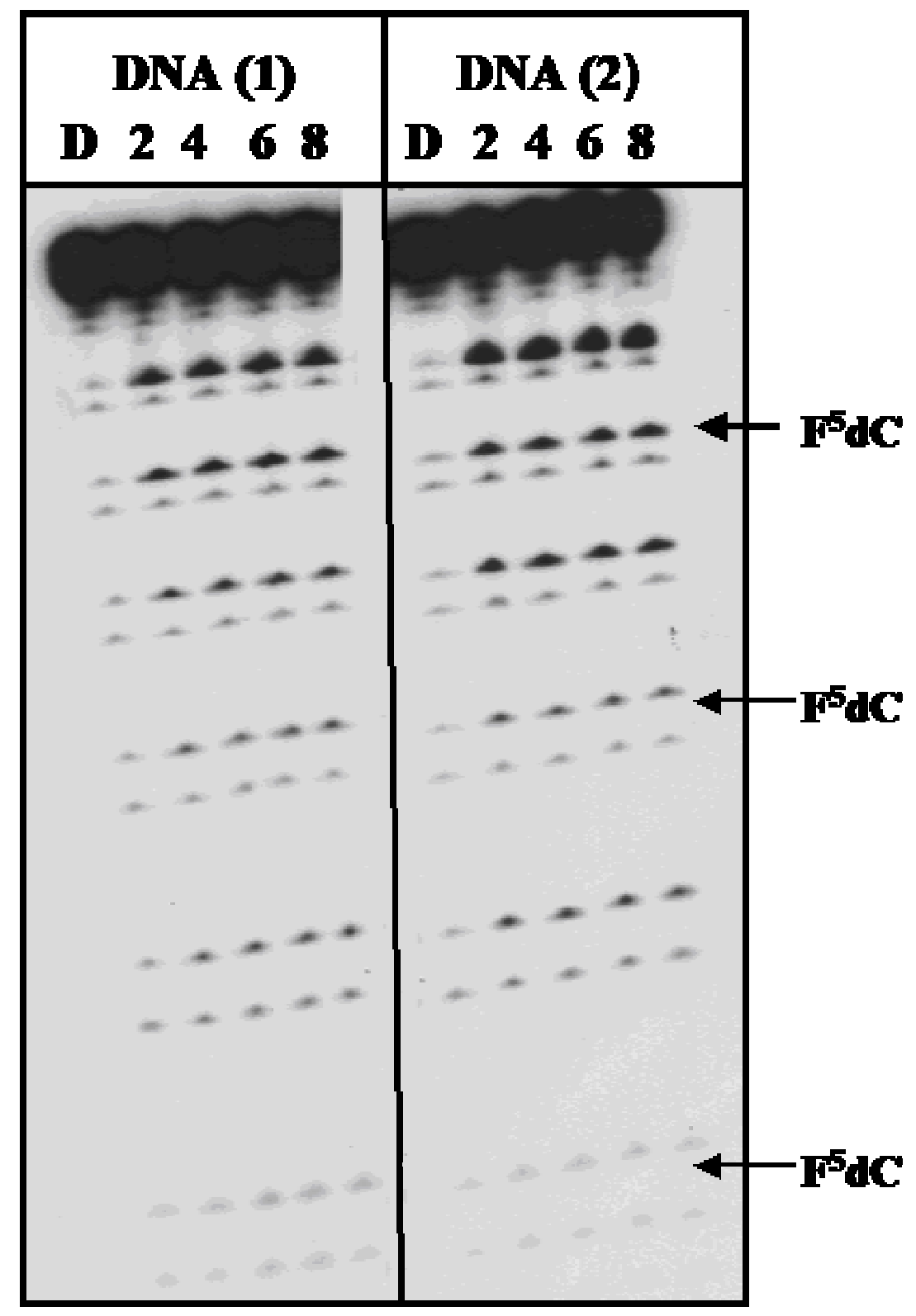

Figure S4. A control experiment to assess the affect of $\mathrm{F}^{5} \mathrm{dC}$ substitution on the efficiency of the reaction of oxidized guanine with Fpg. Two samples are shown. The first is DNA(1), which contains 
no modified 2'-deoxycytosine, the second is DNA(2), which contains

$\mathrm{F}^{5} \mathrm{dC}$ at positions 2, 4 and 6 opposite the GG steps. Each sample (except for the dark controls) was irradiated for 4 min (two lamps) under standard conditions. Following irradiation each sample was treated with an excess of Fpg. The samples were allowed to react at $37^{\circ} \mathrm{C}$ in standard Fpg buffer solution and were stopped by denaturation at $90^{\circ} \mathrm{C}$ after 2, 4, 6, and $8 \mathrm{~h}$. High-resolution PAGE analysis (shown here) of each sample was carried out according to the usual protocol. The results show that there is no inhibition of Fpg reactivity by $\mathrm{F}^{5} \mathrm{dC}$ and that the reaction is complete after $2 \mathrm{~h}$.

Phosphorimagery shows no statistical difference in reactivity between sites that contain $\mathrm{F}^{5} \mathrm{dC}$ and those that contain $\mathrm{dC}$. 
Figure S5. Circular dichroism spectra of DNA(1) and DNA(2)

recorded in buffer solution at $\mathrm{pH} 7$ and room temperature.

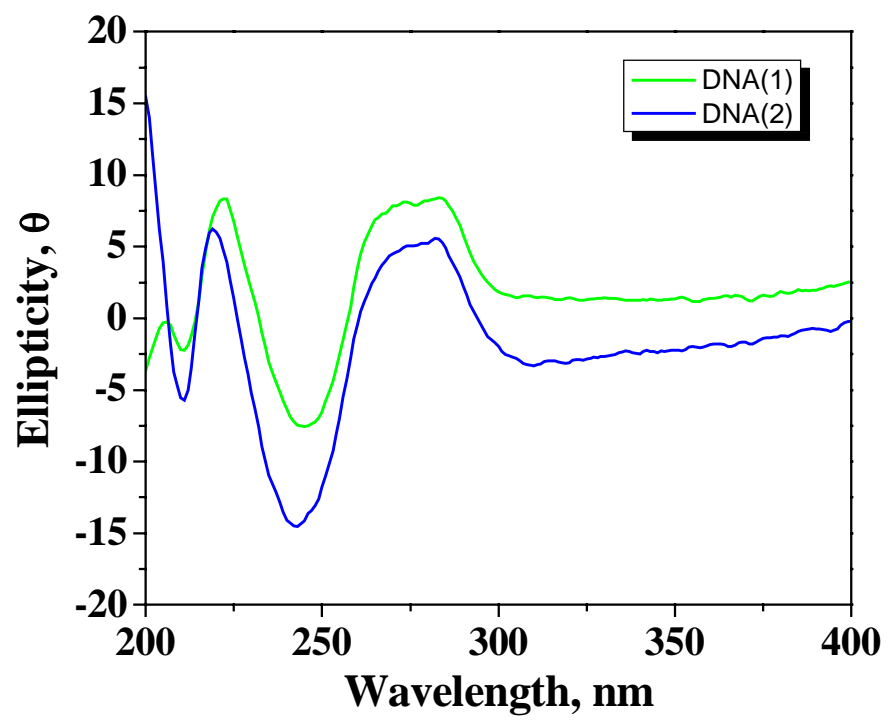

\begin{tabular}{|c|c|}
\hline DNA & Tm \\
\hline DNA (1) & $54^{\circ} \mathrm{C}$ \\
\hline DNA (2) & $54^{\circ} \mathrm{C}$ \\
\hline
\end{tabular}

Table S1. Melting temperature data $\mathrm{T}_{\mathrm{m}}$ for $\mathrm{DNA}(1)$ and $\mathrm{DNA}(2)$

recorded in buffer solution at $\mathrm{pH} 7.0$, the concentration of the duplex

DNA is $4 \mu \mathrm{M}$. 